\title{
APLIKASI ALGORITMA GENETIKA UNTUK MERAMALKAN KONSUMSI PREMIUM KOTA DENPASAR
}

\author{
Victor Mallang ${ }^{1}$, Ketut Jayanegara ${ }^{\S 2}$, Made Asih ${ }^{3}$, I Putu Eka N. Kencana ${ }^{4}$ \\ ${ }^{1}$ Jurusan Matematika, Fakultas MIPA - Universitas Udayana [Email: victormallang@gmail.com] \\ 2 Jurusan Matematika, Fakultas MIPA - Universitas Udayana [Email: ketut_jayanegara@yahoo.com] \\ ${ }^{3}$ Jurusan Matematika, Fakultas MIPA - Universitas Udayana [Email: asihmath77@ gmail.com] \\ ${ }^{4}$ Jurusan Matematika, Fakultas MIPA - Universitas Udayana [Email: i.putu.enk@ gmail.com] \\ ${ }^{\S}$ Corresponding Author
}

\begin{abstract}
This research aimed to forecast the gasoline demand at Denpasar using genetic algorithm method. This algorithm was selected because of easy to implement and its ability to find acceptable solution quickly. This algorithm works by searching the best individu according to fitness function defined. The series data used in the research were 60 observations of monthly gasoline demand at Denpasar for period January 2009 through December 2013. By observing the Partial Autocorrelation Function (PACF) plot, we found the last lag before the series become stationer was sixth lag. Based on this finding, we decided the best individu was represented by six genes. This individu, in addition, was used to make in-sample forecasting. The forecasted data had mean absolute error (MAE) as much as 553,27 kiloliters. For one semester out-of sample forecast, we found gasoline consumption fluctuated with lowest and highest consumption were for February 2014 and June 2014, respectively.
\end{abstract}

Keywords: forecasting, gasoline demand, genetic algorithm, MAE

\section{PENDAHULUAN}

Berbagai teknik peramalan data runtun waktu senantiasa berkembang seiring dengan kebutuhan yang meningkat terhadap keakuratan hasil peramalan yang diperoleh. Secara umum, teknik peramalan data runtun waktu bisa diklasifikasikan ke dalam kelompok teknik peramalan statistika dan kelompok teknik peramalan non-statistika. Model-model moving average, pemulus eksponensial dan berbagai varian dari Autoregressive Integrated Moving Average (ARIMA) tergolong ke dalam kelompok pertama; dan fuzzy time series (FTS) serta algoritma genetika tergolong ke dalam kelompok kedua yang juga dikenal sebagai soft modeling technology [1].

Sebagai sebuah metode peramalan dalam kelompok soft modeling, algoritma genetika merupakan algoritma pencarian yang didasarkan kepada mekanisme seleksi genetika alamiah. Algoritma genetika dimulai dengan membentuk sejumlah solusi yang disebut populasi. Setiap solusi dari populasi pada algoritma ini diwakili oleh satu individu atau kromosom.

Algoritma genetika pada awalnya digunakan sebagai algoritma pencarian parameter-parameter pada permasalahan optimasi. Perkembangan berikut dari algoritma ini adalah mulai diaplikasikannya dalam berbagai ranah permasalahan seperti teori pembelajaran, pemrograman otomat, peramalan dan lainnya [2].

Bahan bakar minyak (BBM) merupakan komoditas yang memegang peranan sangat penting dalam semua aktifitas ekonomi khususnya sebagai bahan bakar kendaraan bermotor. Di Indonesia BBM yang digunakan pada kendaraan bermotor adalah premium, solar, biosolar, pertamax, dan pertamax plus yang diproduksi oleh PT. Pertamina [3].

Berdasarkan latar belakang yang telah dipaparkan, maka akan dilakukan sebuah penelitian yaitu tentang bagaimana peramalan jumlah kebutuhan BBM jenis premium menggunakan algoritma genetika. 


\section{METODE PENELITIAN}

Data yang digunakan dalam penelitian ini merupakan data sekunder yang diperoleh dari PT. Pertamina Bali. Data tersebut berupa data bulanan jumlah konsumsi premium kota Denpasar, periode Januari 2009 sampai Desember 2013.

Representasi kromosom yang digunakan pada penelitian ini adalah:

$$
\hat{Z}_{t}=a_{0}+a_{1} Z_{t-1}+a_{2} Z_{t-2}+\cdots \cdots+a_{i} Z_{t-i}
$$

dengan besar $a_{i}$ merupakan gen dan $i=$ $1,2,3, \ldots, k$. Nilai $k$ dilihat dari lag terakhir yang melebihi batas error sebelum data mencapai kestasioneran.

Terdapat 4 parameter genetika yang digunakan dalam penelitian ini, yaitu sebagai berikut:

1. generasi $=500$ iterasi

2. прор $=50$ individu

3. probabilitas crossover (Pcros) $=80 \%$

4. probabilitas mutasi $($ Pmut $)=50 \%$

Langkah-langkah analisis data yang dilakukan dalam penelitian ini sebagai berikut:

1. Mencari model input.

a. Plot data deret waktu untuk melihat apakah data sudah stasioner atau belum, data memiliki trend, dan linier.

b. Jika data tidak stasioner, maka akan dilakukan differencing untuk menstasionerkan data.

c. Setelah data stasioner maka akan dicari pola data berdasarkan plot ACF dan PACF, yang akan digunakan sebagai model input pada representasi kromosom algoritma genetika.

2. Mencari populasi, batas atas dan bawah selang pembangkit populasi acak, dengan meregresikan sampel data berdasarkan model input yang diperoleh.

3. Melakukan proses algoritma genetika untuk mendapat koefisien linier, dengan langkahlangkah sebagai berikut:

a. Inisialisasi populasi awal.

b. Evaluasi nilai fitness pada setiap individu dalam generasi menggunakan persamaan $M A E=\frac{1}{n} e_{i}$ dengan $e_{i}=\left|z_{t}-\hat{z}_{t}\right|$ c. Seleksi orang tua menggunakan metode steady state

d. Melakukan crossover menggunakan persamaan

$$
\begin{aligned}
& z^{\prime}(k)=r \cdot z_{i}(k)+(1-r) \cdot z_{i}(k+1) \\
& z^{\prime}(k+1)=(1-r) \cdot z_{i}(k)+r \cdot z_{i}(k+1)
\end{aligned}
$$

e. Melakukan mutasi dengan metode pemilihan nilai secara acak (random).

f. Melakukan elitisme dan seleksi populasi baru. Ulangi langkah $c$ sampai $g$ sebanyak generasi.

g. Individu yang memiliki nilai fitness terkecil akan menjadi model linier terbaik.

4. Melakukan peramalan in-sample jumlah kebutuhan BBM jenis premium tahun 2009 sampai 2013.

5. Melakukan peramalan out of sample jumlah kebutuhan BBM jenis premium, pada Bulan Januari, Pebruari, Maret, dan April tahun 2014.

\section{HASIL PENELITIAN DAN DISKUSI}

Langkah awal yang dilakukan untuk menganalisis data jumlah kebutuhan BBM jenis Premium adalah

\section{A. Mecari Model Input}

Plot time series untuk mencari gambaran umum tentang pola data. Berikut ini diagram plot time series data konsumsi premium bulan Januari 2009 sampai bulan Desember tahun 2013.

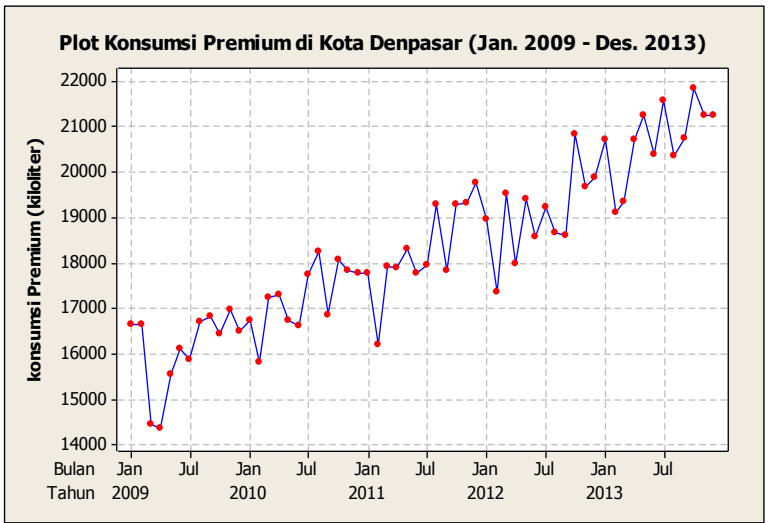

Gambar 3.1 Plot Data Time Series Konsumsi Premium di Kota Denpasar

Setelah mendapatkan pola data time series seperti yang ditunjukkan pada Gambar 3.1, bisa dilihat bahwa data menunjukkan ada pengaruh 
trend dan ketidak-stasioner dikare-nakan data menyebar tidak seimbang (mean tidak konstan), untuk memperjelas apakah mean konstan atau tidak dan ada pengaruh trend, maka dibuat Plot Fungsi Autoco-rrelation, Plot Fungsi Partial Autocorrelation, dan Plot Analisis Trend seperti Gambar berikut:

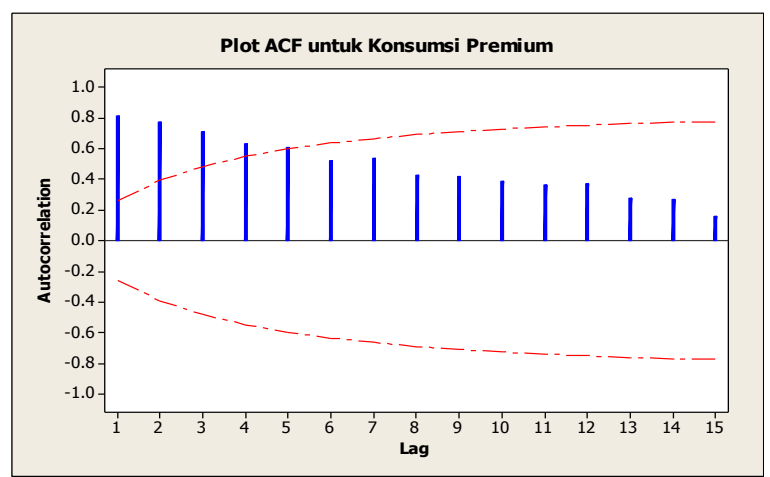

(a)

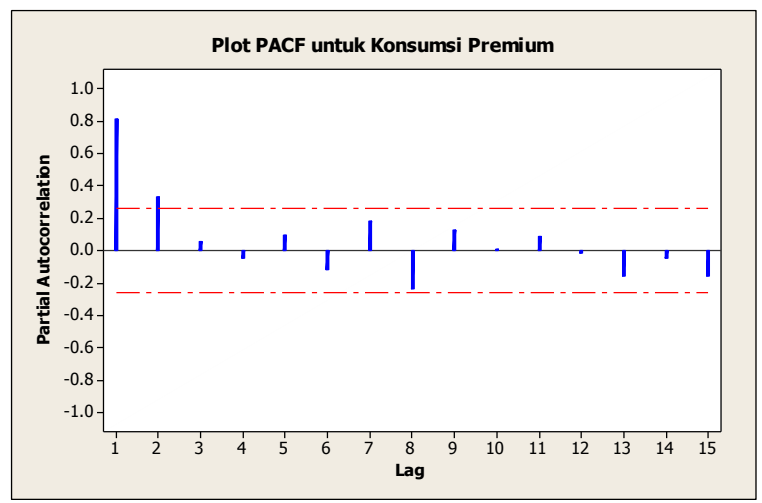

(b)

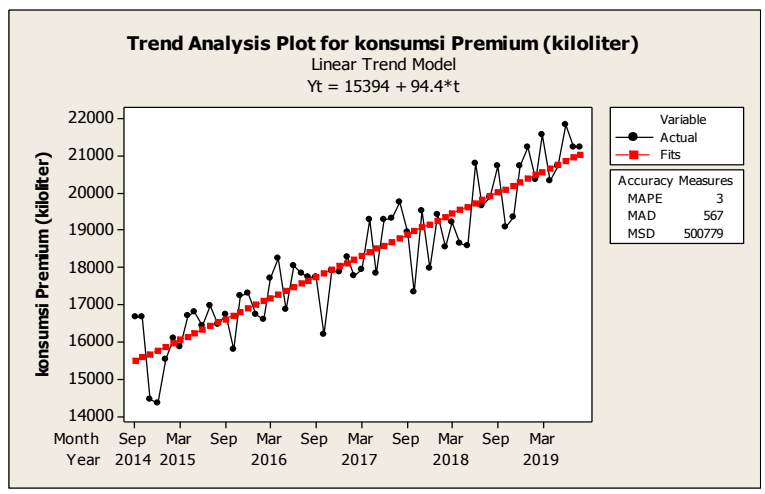

(c)

Gambar 3.2 (a). Plot Fungsi Autocorrelation, (b). Plot Fungsi Partial Autocorrelation, dan (c) Plot Analisis Trend

Gambar 3.2 (a) menunjukkan bahwa data belum stasioner terhadap mean, sedangkan (c), menunjukkan ada pengaruh trend yang linier pada data konsumsi premium Kota Denpasar.
Setelah mengetahui bahwa data belum stasioner, maka dilakukan differencing orde pertama untuk menstasionerkan data. Setelah differencing orde pertama pada data konsumsi premium Kota Denpasar dilakukan, diperoleh data yang sudah stasioner dalam mean, karena sudah menyebar seimbang (mean konstan). Plot data time series konsumsi premium Kota Denpasar yang telah didifferencing:

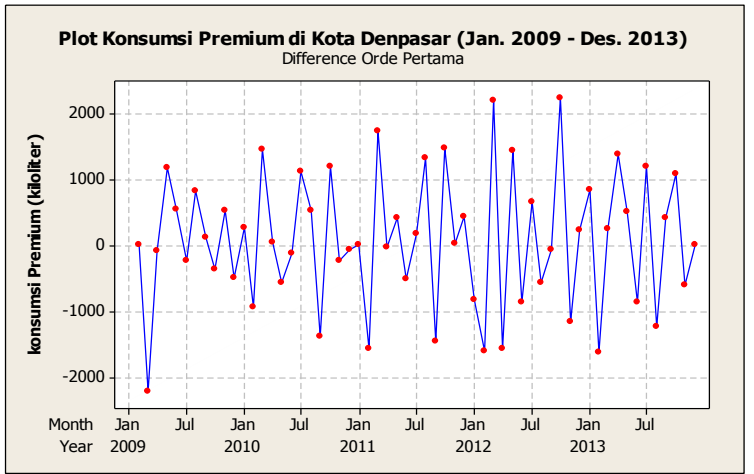

Gambar 3.3 Plot Time Series Differencing

Selanjutnya untuk mengetahui pola data sebenarnya, maka dibuat Plot Fungsi Autocorrelation, Plot Fungsi Partial Autocorrelation.

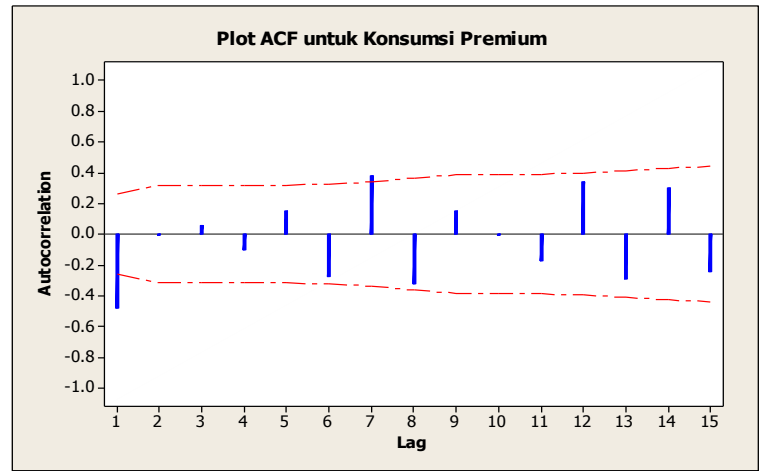

(a)

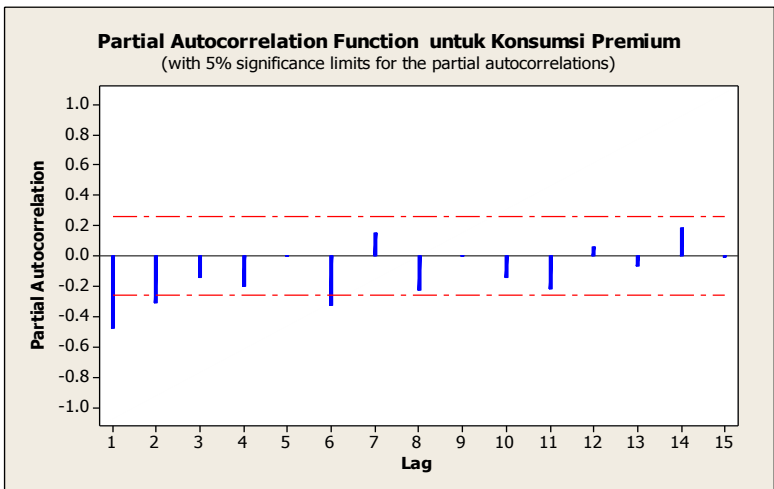

(b)

Gambar 3.4 (a) Plot ACF Data Differencing. dan (b) Plot PACF Data Differencing. 
Gambar 3.4 memperlihatkan bahwa data jumlah konsumsi premium Kota Denpasar sudah stasioner dan pada plot PACF bisa dilihat bahwa dua lag pertama yang melebihi batas standar error yaitu lag 1, lag 2, dan lag 6 sehingga model input pada representasi algoritma genetika yang akan digunakan yaitu:

Tabel 3.1 Model Input algoritma Genetika

\begin{tabular}{|c|c|}
\hline No & Model Input \\
\hline 1 & $\hat{Z}_{t}=a_{0}+a_{1} Z_{t-1}$ \\
\hline 2 & $\hat{Z}_{t}=a_{0}+a_{1} Z_{t-1}+a_{2} Z_{t-2}$ \\
\hline 3 & $\hat{Z}_{t}=a_{0}+a_{1} Z_{t-1}+a_{2} Z_{t-2}+a_{3} Z_{t-3}$ \\
\hline 4 & $\hat{Z}_{t}=a_{0}+a_{1} Z_{t-1}+a_{2} Z_{t-2}+a_{3} Z_{t-3}+a_{4} Z_{t-4}$ \\
\hline 5 & $\begin{aligned} \hat{Z}_{t}= & a_{0}+a_{1} Z_{t-1}+a_{2} Z_{t-2}+a_{3} Z_{t-3}+a_{4} Z_{t-4} \\
& +a_{5} Z_{t-5}\end{aligned}$ \\
\hline 6 & $\begin{aligned} \hat{Z}_{t}= & a_{0}+a_{1} Z_{t-1}+a_{2} Z_{t-2}+a_{3} Z_{t-3}+a_{4} Z_{t-4} \\
& +a_{5} Z_{t-5}+a_{6} Z_{t-6}\end{aligned}$ \\
\hline 7 & $\hat{Z}_{t}=a_{0}+a_{1} Z_{t-1}+a_{2} Z_{t-2}+a_{6} Z_{t-6}$ \\
\hline 8 & $\begin{aligned} \hat{Z}_{t}= & a_{1} Z_{t-1}+a_{2} Z_{t-2}+a_{3} Z_{t-3}+a_{4} Z_{t-4} \\
& +a_{5} Z_{t-5}+a_{6} Z_{t-6}\end{aligned}$ \\
\hline
\end{tabular}

\section{B. Tahap Pencarian Populasi dan Selang Populasi Acak}

Berdasarkan representasi kromosom yang telah dibentuk dari model input, data konsumsi premium Kota Denpasar kemudian diregresikan menggunakan masing-masing representasi kromosom untuk memperoleh populasi dan selang pembangkit populasi.

Regresi dilakukan dengan mengambil 30 data secara terurut menggunakan software microsoft excel, sehingga diperoleh 30 individu dari model input 1, 29 individu dari model input 2, 28 individu dari model input 3, 27 individu dari model input 4, 26 individu dari model input 5, dan 25 individu dari model input 6, 7, dan 8. Individu dari masing-masing model, dicari nilai minimum dan maksimum yang akan digunakan untuk membangkit individu lain yang mungkin belum muncul pada populasi hasil regresi.

\section{Pencarian Individu Terbaik}

Peramalan dengan algoritma genetika ini menggunakan pengkodean real dengan simulasi program menggunakan software matlab R2012b. Pada tahap ini, masing-masing model kemudian dicari individu yang memiliki nilai fitness terkecil, sehingga diperoleh delapan individu terbaik yang memiliki fitness terkecil.

Individu-individu tersebut kemudian dibandingkan satu sama lain sehingga diperoleh satu individu terbaik yang akan digunakan untuk peramalan data jumlah kebutuhan BBM jenis premium Kota Denpasar. Tahapan peramalan menggunakan algoritma genetika adalah sebagai berikut:

\section{Inisialisasi Populasi Awal}

Populasi yang telah dibentuk dari proses regresi kemudian ditambahkan dengan sejumlah populasi baru yang dibangkitkan secara acak dari selang nilai minimum dan maksimum, sehingga populasi awal yang diperoleh berjumlah 50 individu.

\section{Evaluasi Nilai Fitness}

Individu pada populasi yang telah diinisialisasi tadi, kemudian dihitung nilai fitnessnya dan diurutkan secara ascending berdasarkan nilai fitness. Setelah evaluasi fitness dilakukan, langkah selanjutnya adalah melakukan proses evolusi yaitu seleksi orang tua, crossover, mutasi, dan elitisme dengan pengulangan sebanyak generasi $=500$.

\section{Seleksi Orang Tua}

Seleksi orang tua yang digunakan adalah seleksi steady state, metode ini dilakukan dengan cara mengambil individu terbaik sebagai orang tua sebanyak $50 \%$ (25 individu) dari populasi yang telah terurut. Kemudian individu yang terseleksi tersebut diinisialisasikan sebagai $\operatorname{ortu}(1)$, ortu(2) hingga ortu(25).

\section{Crossover}

Orang tua yang telah terpilih menggunakan metode steady state, kemudian dikawinsilangkan (crossover) dengan probabilitas crossover (Pcros) $=80 \%$ menggunakan metode arithmatic-crossover. Hasil dari proses crossover disebut sebagai offspring dan diinisialisasikan sebagai anak dan akan dimasukan ke dalam populasi, sehingga jumlah populasi akan bertambah. 
Mutasi

Populasi yang telah bertambah sebelumnya akan dimutasi dengan probabilitas mutasi Pmut $=50 \%$. Proses mutasi dilakukan dengan cara mengganti nilai gen (allele) pada locus yang memiliki probabilitas terpilih kurang dari Pmut dengan nilai acak pada selang $[0,1]$. Individuindividu yang mengalami mutasi, akan diinisialisasikan sebagai individu baru dan dimasukkan ke dalam populasi.

Elitisme dan Seleksi Populasi

Setelah proses seleksi orang tua, crossover, dan mutasi dilakukan, proses elistime dilakukan dengan cara menghitung nilai fitness individu dalam populasi dan diurutkan berdasarkan nilai fitnessnya secara ascending kemudian individu yang terpilih menjadi populasi selanjutnya adalah 50 individu terbaik pertama.

\section{Individu Terbaik}

Dari proses seleksi, crossover, mutasi, elitisme, dan seleksi populasi diperoleh individu terbaik yang memiliki nilai fitness terkecil, ditunjukkan pada tabel berikut ini:
Tabel 3.2 Individu Terbaik dari Kedelapan Model

\begin{tabular}{|c|l|l|}
\hline $\begin{array}{c}\text { Model } \\
\text { Input }\end{array}$ & \multicolumn{1}{|c|}{ Individu } & \multicolumn{1}{|c|}{$\begin{array}{c}\text { Fitness } \\
\text { (MAE) }\end{array}$} \\
\hline 1 & $3108,12350,8303$ & 773,4156 \\
\hline 2 & $3253,40060,39330,4402$ & 688,9503 \\
\hline 3 & $1985,48370,28090,37220,2490$ & 617,7826 \\
\hline 4 & $2205,10630,25120,28180,12370,2407$ & 571,2109 \\
\hline 5 & $\begin{array}{l}1689,20600,09970,25500,19960,2559 \\
0,1221\end{array}$ & 562,5746 \\
\hline $\mathbf{6}$ & $\begin{array}{l}\mathbf{1 0 7 1 , 6 5 0 1} \mathbf{- 0 , 0 3 2 7} \mathbf{0 , 2 8 4} \mathbf{0 , 2 3 6 1 0 , 2 2 5 6} \\
\mathbf{0 , 0 5 4 0 ~ 0 , 1 9 8 8}\end{array}$ & $\mathbf{5 5 3 , 2 5 6 0}$ \\
\hline 7 & $2256,77350,18890,36380,3450$ & 595,7843 \\
\hline 8 & $-0,02440,25940,24960,18600,08540,2692$ & 559,7168 \\
\hline
\end{tabular}

Tabel 3.2 menunjukkan bahwa individu tebaik dengan fitness terkecil yaitu individu dari model input keenam, sehingga model peramalan yang diperoleh adalah:

$$
\begin{aligned}
\hat{Z}_{t}= & 1071.6501-0.0327 * Z_{t-1}+0.284 * Z_{t-2} \\
& 0.2361 * Z_{t-3}+0.2256 * Z_{t-4}+0.054 * Z_{t-5} \\
& +0.1988 * Z_{t-6}
\end{aligned}
$$

Persamaan (3.1) akan digunakan untuk meramalkan jumlah kebutuhan BBM jenis premium Kota Denpasar periode Bulan Januari 2014 hingga Juni 2014.

\section{Peramalan In-sample Jumlah Konsumsi Premium}

Grafik peramalan in-sample jumlah kebutuhan BBM jenis premium dapat dilihat pada Gambar berikut:

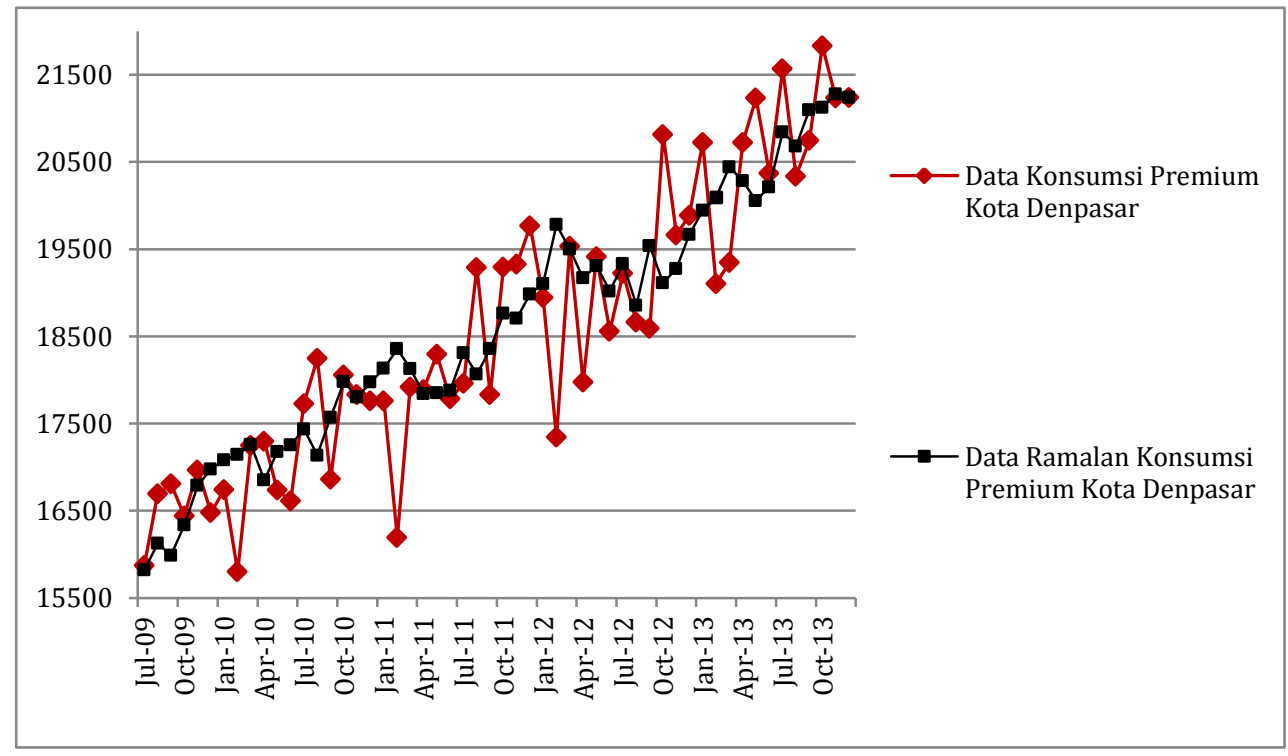

Gambar 3.5 Peramalan Jumlah Kebutuhan Premium Kota Denpasar Tahun 2013 
Gambar 3.5 merupakan grafik uji model linier untuk peramalan in-sample jumlah kebutuhan premium di Kota Denpasar $M A E=553,2690$ kiloliter dan $M A P E=3,0217 \%$.

\section{E. Peramalan Out of Sample Jumlah Konsumsi Premium}

Grafik hasil peramalan jumlah konsumsi premium Kota Denpasar Bulan Januari hingga Juni tahun 2014 dapat dilihat pada Gambar 3.6 sebagai berikut:

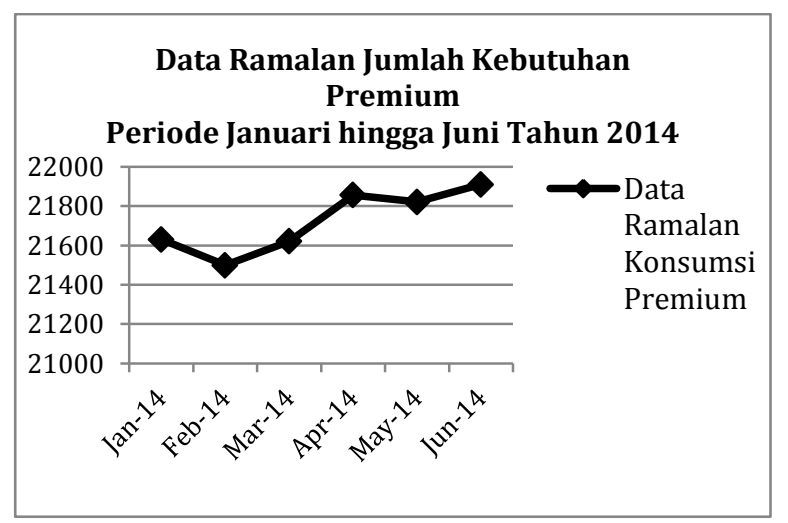

Gambar 3.6 Peramalan Out of Sample Jumlah Kebutuhan Premium Kota Denpasar

Gambar 3.6 menunjukkan bahwa jumlah konsumsi premium di Kota Denpasar mengalami flukstuasi dengan rata-rata jumlah kebutuhan premium Kota Denpasar sebesar 21722,85935 kiloliter. Hasil peramalan menunjukkan bahwa jumlah konsumsi premium terbesar di Kota Denpasar terjadi pada Bulan Juni 2014 yaitu 21910,3237 kiloliter dan jumlah konsumsi premium terendah terjadi pada bulan Pebruari 2014 yaitu 21499,2790 kiloliter.

\section{SIMPULAN DAN REKOMENDASI}

A. Simpulan Penelitian

Berdasarkan hasil yang telah diperoleh pada kasus peramalan jumlah kebutuhan premium tahun 2014, maka dapat ditarik kesimpulan bahwa:

Kinerja algoritma genetika dalam meramalkan jumlah kebutuhan BBM jenis premium di Kota Denpasar cukup baik dengan nilai error yang dihasilkan yaitu MAE sebesar 553,2690 dan MAPE sebesar 3.0217\%.

Penggunaan BBM jenis premium di Kota Denpasar, mengalami fluktuasi dengan rata-rata jumlah kebutuhan premium sebesar 21722,85935 kiloliter.

B. Rekomendasi

Dari simpulan di atas akan disampaikan beberapa saran yang dapat dijadikan pertimbangan, saran tersebut antara lain:

1. Algoritma genetika pada penelitian ini menggunakan pengkodean real, sehingga mungkin untuk penelitian lebih lanjut dapat menggunakan pengkodean biner.

2. Melakukan perbandingan metode peramalan menggunakan algoritma genetika dengan metode peramalan yang lain.

\section{DAFTAR PUSTAKA}

[1] Patria, D.P.N., 2009. "Penerapan Algoritma Genetika Dalam Pencarian Nilai Parameter Untuk Peramalan Data Penjualan Secara Time Series". Skripsi. Malang: Universitas Brawijaya.

[2] Suyanto. 2011. Artificial Intelligence (Searching-Reasoning-Planning-Learning). Edisi revisi. Bandung: Informatika.

[3] Utari, P.D., 2011. "Prediksi Permintaan BBM Di PT. Pertamina Region V Dengan Metode Peramalan Data Time Series Hirarki". Jurnal FMIPA-ITS. Surabaya: Institut Teknologi Sepuluh November. 


\section{LAMPIRAN}

Output Program Peramalan In-sample

$\mathrm{Z}(\mathrm{t}-6) \mathrm{Z}(\mathrm{t}-5) \mathrm{Z}(\mathrm{t}-4) \mathrm{Z}(\mathrm{t}-3) \mathrm{Z}(\mathrm{t}-2) \mathrm{Z}(\mathrm{t}-1) \quad \mathrm{z}(\mathrm{t}) \quad \mathrm{z}$ duga error $\begin{array}{lllllllll}16656 & 16656 & 14448 & 14360 & 15544 & 16096 & 15872 & 15820.3085 & 51.6915\end{array}$ $\begin{array}{llllllllll}16656 & 14448 & 14360 & 15544 & 16096 & 15872 & 16696 & 16124.8589 & 571.1411\end{array}$ $\begin{array}{lllllllll}14448 & 14360 & 15544 & 16096 & 15872 & 16696 & 16808 & 15988.0333 & 819.9667\end{array}$ $\begin{array}{lllllllll}14360 & 15544 & 16096 & 15872 & 16696 & 16808 & 16440 & 16336.4733 & 103.5267\end{array}$ $\begin{array}{llllllllll}15544 & 16096 & 15872 & 16696 & 16808 & 16440 & 16968 & 16789.5141 & 178.4859\end{array}$ $\begin{array}{llllllllll}16096 & 15872 & 16696 & 16808 & 16440 & 16968 & 16480 & 16977.7157 & 497.7157\end{array}$ $\begin{array}{llllllllll}15872 & 16696 & 16808 & 16440 & 16968 & 16480 & 16744 & 17081.9725 & 337.9725\end{array}$ $\begin{array}{lllllllll}16696 & 16808 & 16440 & 16968 & 16480 & 16744 & 15800 & 17146.2469 & 1346.2469\end{array}$ $\begin{array}{llllllllll}16808 & 16440 & 16968 & 16480 & 16744 & 15800 & 17248 & 17258.3853 & 10.3853\end{array}$ $\begin{array}{llllllllll}16440 & 16968 & 16480 & 16744 & 15800 & 17248 & 17296 & 16850.5309 & 445.4691\end{array}$ $\begin{array}{lllllllll}16968 & 16480 & 16744 & 15800 & 17248 & 17296 & 16736 & 17175.4877 & 439.4877\end{array}$ $\begin{array}{llllllllll}16480 & 16744 & 15800 & 17248 & 17296 & 16736 & 16616 & 17253.5797 & 637.5797\end{array}$ $\begin{array}{lllllllll}16744 & 15800 & 17248 & 17296 & 16736 & 16616 & 17728 & 17437.9725 & 290.0275\end{array}$ $\begin{array}{llllllllll}15800 & 17248 & 17296 & 16736 & 16616 & 17728 & 18248 & 17136.6677 & 1111.3323\end{array}$ $\begin{array}{llllllllll}17248 & 17296 & 16736 & 16616 & 17728 & 18248 & 16864 & 17571.2581 & 707.2581\end{array}$ $\begin{array}{llllllllll}17296 & 16736 & 16616 & 17728 & 18248 & 16864 & 18056 & 17978.9685 & 77.0315\end{array}$ $\begin{array}{llllllllll}16736 & 16616 & 17728 & 18248 & 16864 & 18056 & 17832 & 17802.7653 & 29.2347\end{array}$ $\begin{array}{llllllllll}16616 & 17728 & 18248 & 16864 & 18056 & 17832 & 17760 & 17975.3597 & 215.3597\end{array}$ $\begin{array}{lllllllll}17728 & 18248 & 16864 & 18056 & 17832 & 17760 & 17760 & 18132.4445 & 372.4445\end{array}$ $\begin{array}{llllllllll}18248 & 16864 & 18056 & 17832 & 17760 & 17760 & 16192 & 18356.6653 & 2164.6653\end{array}$ $\begin{array}{lllllllll}16864 & 18056 & 17832 & 17760 & 17760 & 16192 & 17720 & 18129.6341 & 409.6341\end{array}$ $\begin{array}{llllllllll}18056 & 17832 & 17760 & 17760 & 16192 & 17720 & 17888 & 17842.9869 & 45.0131\end{array}$ $\begin{array}{llllllllll}17832 & 17760 & 17760 & 16192 & 17720 & 17888 & 18296 & 17852.8213 & 443.1787\end{array}$ $\begin{array}{llllllllll}17760 & 17760 & 16192 & 17720 & 17888 & 18296 & 17784 & 17879.8981 & 95.8981\end{array}$ $\begin{array}{lllllllll}17760 & 16192 & 17720 & 17888 & 18296 & 17784 & 17960 & 18312.2221 & 352.2221\end{array}$ $\begin{array}{lllllllll}16192 & 17720 & 17888 & 18296 & 17784 & 17960 & 19288 & 18066.0821 & 1221.9179\end{array}$ $\begin{array}{llllllllll}17720 & 17888 & 18296 & 17784 & 17960 & 19288 & 17832 & 18356.6405 & 524.6405\end{array}$ $\begin{array}{lllllllll}17888 & 18296 & 17784 & 17960 & 19288 & 17832 & 19296 & 18762.8805 & 533.1195\end{array}$ $\begin{array}{lllllllll}18296 & 17784 & 17960 & 19288 & 17832 & 19296 & 19328 & 18708.2125 & 619.7875\end{array}$ $\begin{array}{llllllllll}17784 & 17960 & 19288 & 17832 & 19296 & 19328 & 19768 & 18986.4957 & 781.5043\end{array}$ $\begin{array}{llllllllll}17960 & 19288 & 17832 & 19296 & 19328 & 19768 & 18944 & 19105.0733 & 161.0733\end{array}$ $\begin{array}{llllllllll}19288 & 17832 & 19296 & 19328 & 19768 & 18944 & 17344 & 19780.1941 & 2436.1941\end{array}$ $\begin{array}{llllllllll}17832 & 19296 & 19328 & 19768 & 18944 & 17344 & 19536 & 19499.2045 & 36.7955\end{array}$ $\begin{array}{llllllllll}19296 & 19328 & 19768 & 18944 & 17344 & 19536 & 17976 & 19170.6149 & 1194.6149\end{array}$ $\begin{array}{lllllllll}19328 & 19768 & 18944 & 17344 & 19536 & 17976 & 19416 & 19310.6221 & 105.3779\end{array}$ $\begin{array}{lllllllll}19768 & 18944 & 17344 & 19536 & 17976 & 19416 & 18560 & 19020.0413 & 460.0413\end{array}$ $\begin{array}{llllllllll}18944 & 17344 & 19536 & 17976 & 19416 & 18560 & 19224 & 19332.9805 & 108.9805\end{array}$ $\begin{array}{llllllllll}17344 & 19536 & 17976 & 19416 & 18560 & 19224 & 18664 & 18856.4997 & 192.4997\end{array}$ $\begin{array}{llllllllll}19536 & 17976 & 19416 & 18560 & 19224 & 18664 & 18592 & 19537.6797 & 945.6797\end{array}$ $\begin{array}{lllllllll}17976 & 19416 & 18560 & 19224 & 18664 & 18592 & 20816 & 19112.2829 & 1703.7171\end{array}$ $\begin{array}{lllllllll}19416 & 18560 & 19224 & 18664 & 18592 & 20816 & 19664 & 19276.7405 & 387.2595\end{array}$ $\begin{array}{lllllllll}18560 & 19224 & 18664 & 18592 & 20816 & 19664 & 19888 & 19668.3749 & 219.6251\end{array}$ $\begin{array}{lllllllll}19224 & 18664 & 18592 & 20816 & 19664 & 19888 & 20722 & 19944.4885 & 777.5115\end{array}$ $\begin{array}{llllllllll}18664 & 18592 & 20816 & 19664 & 19888 & 20722 & 19106 & 20095.3639 & 989.3639\end{array}$ $\begin{array}{llllllllll}18592 & 20816 & 19664 & 19888 & 20722 & 19106 & 19346 & 20283.8407 & 937.8407\end{array}$ $\begin{array}{lllllllll}20816 & 19664 & 19888 & 20722 & 19106 & 19346 & 20722 & 20444.4137 & 277.5863\end{array}$ $\begin{array}{llllllllll}19664 & 19888 & 20722 & 19106 & 19346 & 20722 & 21234 & 20057.2697 & 1176.7303\end{array}$ $19888207221910619346207222123420370 \quad 20212.9729 \quad 157.0271$ $2072219106 \quad 1934620722 \quad 2123420370 \quad 21570 \quad 20844.1865 \quad 725.8135$ $\begin{array}{lllllllll}19106 & 19346 & 20722 & 21234 & 20370 & 21570 & 20338 & 20682.5785 & 344.5785\end{array}$ $\begin{array}{lllllllll}19346 & 20722 & 21234 & 20370 & 21570 & 20338 & 20746 & 21097.1977 & 351.1977\end{array}$ $\begin{array}{lllllllll}20722 & 21234 & 20370 & 21570 & 20338 & 20746 & 21834 & 21123.5665 & 710.4335\end{array}$ $2123420370 \quad 21570 \quad 20338 \quad 20746218342123621238.8353 \quad 2.8353$ $2037021570 \quad 203382074621834 \quad 21236 \quad 21239 \quad 21278.8083 \quad 39.8083$

$\mathrm{MAE}=553.2690$

MAPE $=3.0217$ persen 


$\begin{array}{ll}\text { Output Program Peramalan Out-sample } \\ \text { Bulan } & \text { Data Duga } \\ 1-2014 & 21629.8318 \\ 2-2014 & 21499.2790 \\ 3-2014 & 21620.2062 \\ 4-2014 & 21856.1295 \\ 5-2014 & 21821.3859 \\ 6-2014 & 21910.3237 \\ & \\ \text { Total } & 130337.1561 \\ \text { Minimum } & 21499.2790 \\ \text { Maksimum } & 21910.3237 \\ \text { Rata-rata } & 21722.85935\end{array}$

